\section{A report of the threatened plant Decalepis hamiltonii Wight \& Arn. (Asclepiadaceae) from the mid elevation forests of Pachamalai Hills of the Eastern Ghats, Tamil Nadu, India}

\author{
V. Anburaja ${ }^{1}$, V. Nandagopalan ${ }^{2}$, S. Prakash ${ }^{3} \&$ \\ A. Lakshmi Prabha ${ }^{4}$ \\ 1,2 PG and Research Department of Botany, National College, \\ Tiruchirappalli, Tamil Nadu 620001, India \\ ${ }^{3}$ Post Doctoral Scholar, VOLCANI Centre, Israel \\ ${ }^{4}$ Department of Plant Science, Bharathidasan University, \\ Tiruchirappalli, Tamil Nadu 620024, India \\ Email: ${ }^{1}$ vanburaja@gmail.com (corresponding author), \\ 2veenan05@gmail.com, 33vsham@hotmail.com \\ ${ }^{4}$ dralprabha@yahoo.com
}

The Eastern Ghats are a series of discontinuous low hill ranges running generally northeast-southwest, parallel to the coast of the Bay of Bengal. The Eastern Ghats have a rich floristic diversity; more than 2500 species of angiosperms occur in this region, which constitutes about $13 \%$ of the flowering plants of India

Date of publication (online): 26 December 2012

Date of publication (print): 26 December 2012

ISSN $0974-7907$ (online) | 0974-7893 (print)

Editor: N.P. Balakrishnan

Manuscript details:

Ms \# 03053

Received 04 January 2012

Final received 14 May 2012

Finally accepted 28 September 2012

Citation: Anburaja, V., V. Nandagopalan, S. Prakash \& A.L. Prabha (2012). A report of the threatened plant Decalepis hamiltonii Wight \& Arn (Asclepiadaceae) from the mid elevation forests of Pachamalai Hills of the Eastern Ghats, Tamil Nadu, India. Journal of Threatened Taxa 4(15) $3447-3449$

Copyright: (c) V. Anburaja, V. Nandagopalan, S. Prakash \& A. Lakshm Prabha 2012. Creative Commons Attribution 3.0 Unported License. JoTT allows unrestricted use of this article in any medium for non-profit purposes, reproduction and distribution by providing adequate credit to the authors and the source of publication.

Acknowledgements: We thank the Secretary and Correspondent Thiru. K. Raghunathan and the Principal Dr. K. Anbarasu, National College (Autonomous), Tiruchirappalli for providing facilities during this research work. We also thank Dr. S. Soosai Raj, Assistant Professor, St. Josephs College, Trichirappalli for helping me in plant identification. We are grateful to R. Rajan, and other officials of Botanical Survey of India, Regional Office, Southern Circle, Coimbatore for allowing me to refer the literatures. We thank Dravia Dass (Late) for helping me in the field collection. Our thanks to M. Sivakumar and other local people of the Pachamalai to help me in the field work.

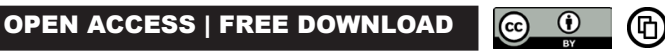

(Nair \& Henry 1983; Saxena \& Brahmam 1994; Pullaiah 1997; Pullaiah \& Alimoulali 1997; Pullaiah \& Chennaiah 1997).

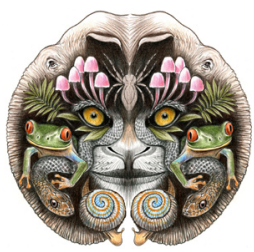

The Eastern Ghats is rich in medicinal and aromatic plant resources and indigenous livelihood traditions, therefore under the framework of proper policy and guidelines, these resources can be more effectively used to benefit local people.

The loss of biodiversity due to the introduction of exotics is damaging native biodiversity. The habitat destruction and conversion by shifting cultivation, rapid industrialization and excessive exploitation of raw materials are some of the reasons for the disappearance of many plants and animals. Apart from these, developmental projects like dam constructions and settlements around have submerged a considerable part of the forests. Forest fires, cattle grazing and mining in the area are also responsible for the biodiversity decline.

The Pachamalai Hills are a part of the Eastern Ghats situated in the central region of Tamil Nadu, India $\left(11^{\circ} 09^{\prime}-11^{0} 27^{\prime} \mathrm{N} \& 7^{0} 28^{\prime}-78^{\circ} 49^{\prime} \mathrm{E}\right.$; Image 1$)$. They occupy an area of about $527.61 \mathrm{~km}^{2}$ and a range of 160-1072 m. The vegetated area is distributed into 35 reserved forests. The Pachamalai Hills enjoy a subtropical climate with temperatures varying from $25-31{ }^{\circ} \mathrm{C}$ and annual rainfall ranging from 800-900 $\mathrm{mm}$. It supports many types of vegetation and of these the dry evergreen forests have been considered significant due to their dense cover, besides their distinct composition. Evergreen forests are relatively common in the Western Ghats of peninsular India; however, dry evergreen forests are meagre in distribution and are confined to higher elevations of the Eastern Ghats that are discontinuous and in small patches. The presence of such vegetation is an indication that the lower elevation hills like the Eastern Ghats can harbour good vegetation and are the vestiges of a luxuriant vegetation cover of the past era and hence need to be protected (Soosairaj et al. 2007). The hills are most significant socio-culturally, as the most diversified forest patches are found here. These hills have been studied earlier mainly for floristic analysis (Matthew 1983).

However, while working on the floral biodiversity of mid elevation forests of Pachamalai Hills, we collected Decalepis hamiltonii Wight \& Arn. in the 


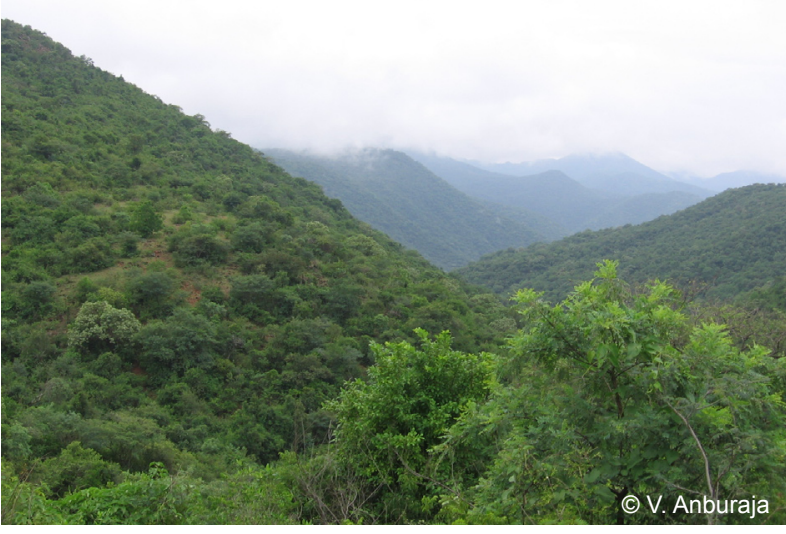

Image 1. A view of the Pachamalai Hills



Image 2. Decalepis hamiltonii with flowers and fruits
Gangavalli Hills, a part of Pachamalai at an altitude of 500-550 m. The plant D. hamiltonii was found as a single population in riparian vegetation of the study area (Image 2). Before this, D. hamiltonii had not been reported from Pachamalai (Matthew 1983).

D. hamiltonii belongs to the family Asclepiadaceae. The habit of the plant is a liana. It is a globally endangered species (Raju \& Ramana 2009). D. hamiltonii is one of the four species in the genus Decalepis. It is endemic to peninsular India and is known by various names like "Maredu Kommulu, Nannari kommulu and Madina Kommulu" in Telugu, "Makali ber" in Kannada and "Magali kizhangu" in Tamil. The plant root is used in ayurvedic medicines and in pickles.

Regeneration is severely affected since most of the plants are harvested prior to seed setting. Roots, leaves and follicles have medicinal properties. Roots are pickled and marketed on a large scale. This plant is also used as a substitute for the real Nannari plant Hemidesmus indicus (L) R. Br. Roots are harvested in hundreds of tonnes from Biligiri Rangaswamy Temple Hills for pickling and medicinal purposes. The Conservator of Forests of Vellore and Salem circle stated that around 100 tonnes of roots are auctioned every year. Girijan Co-operative Society, Andhra Pradesh traded 351.6 tonnes of roots from April 1997 to January 1998.

The tribal community of the Pachamalai Hills utilizes $D$. hamiltonii as ethnomedicine. It is taken orally to rejuvenate the body and is a popular health tonic. Ancient tribes in the Western Ghats of India have also used the roots of $D$. hamiltonii for several medicinal purposes particularly as an anti-inflammatory (Ashalatha et al. 2010). The root contains antioxidants.

Vegetative and reproductive characters: Branchlets terete with swollen, winged nodes. Leaves ovate, subcoriaceous, longitudinally folded, base attenuate, margin entire, apex subacute; petiolate. Cymes axillary peduncled trichotomous cymes; bracts and bracteoles lanceolate; flowers pedicellate. Calyx lobes oblong, tinged with brown, chartaceous, valvate, acute. Corolla cream, campanulate; lobes spreading, valvate, villous inside, acute. Stamens connivent; pollinia horizontal; pollinial bags closely adherent, flat; caudicle indistinct; receptacle minute. Corona double with 10 scales; outer scales truncate; inner flat, adhering to gynostegium. Glands 5 at the base of corolla, alternating with stamens, 2-fid. Ovaries subglobose; style present; stigma obtuse. Follicle oblong - lanceolate, cylindric; epicarp thick, crinkled; seeds ovate; testa angled, chartaceous, tipped with long, white, silky coma.

Phenology: Flowering: May-July. Fruiting: January-March.

Distribution: The species is endemic to peninsular India. It is has been recorded in the dry and moist deciduous forests of Karnataka (Hassan, Mysore, Bellary, Tumkur, Kolar), Andhra Pradesh (Kurnool, Chittoor, Nellore, Anantapur, Cuddapah districts) and Tamil Nadu (Chengalpattu, Coimbatore, Dharmapuri, Nilgiri) 


\section{REFERENCES}

Ashalatha, K., Y. Venkateswarlu, A.M. Priya, P. Lalitha, M. Krishnaveni \& S. Jayachandran (2010). Anti inflammatory potential of Decalepis hamiltonii (Wight \& Arn) as evidenced by down regulation of pro inflammatory cytokines-TNF-alpha and IL-2. Journal of Ethnopharmacology 130 (1): 167-170.

Matthew, K.M. (1983). The Flora of The Tamil Nadu Carnatic-Part II. Rapinat Herbarium Tiruchirappalli, Tamil Nadu, India, 944pp.

Nair, N.C. \& A.N. Henry (1983). Flora of Tamilnadu, IndiaVolume 1. Botanical Survey of India. Southern Circle, Coimbatore.

Pullaiah, T. (1997). Flora of Andhra Pradesh-Volume 3.
Scientific Publishers, Jodhpur.

Pullaiah, T. \& D. Alimoulali (1997). Flora of Andhra Pradesh-Volume 2. Scientific Publishers, Jodhpur.

Pullaiah, T. \& E. Chennaiah (1997). Flora of Andhra Pradesh-Volume 1. Scientific Publishers, Jodhpur.

Raju, A.J.S. \& K.V. Ramana (2009). Pollination and seedling ecology of Decalepis hamiltonii Wight \& Arn. (Periplocaceae), a commercially important, endemic and endangered species. Journal of Threatened Taxa 1(10): 497-506

Soosairaj, S., S.J. Britto, B. Balaguru, N. Nagamurugan \& D. Natarajan (2007). Zonation of conservation priority sites for effective management of tropical forests in India. Applied Ecology and Environmental Research 5(2): 3748. 